\title{
PENGARUH PEMBERIAN PRICE DISCOUNT TERHADAP LOYALITAS KONSUMEN PADA PENGGUNA ONLINE MARKETPLACE
}

\author{
Salsabila Wulandari Aryatinigrum \\ Universitas Negeri Surabaya \\ salsabila.18074@mhs.unesa.ac.id \\ Athiyyah Isna Insyirah \\ Universitas Negeri Surabaya \\ athiyyah.18086@mhs.unesa.ac.id
}

\begin{abstract}
College students are the generation that lives side by side with current communication technology. To conduct activities such as shopping, many college students also use the online marketplace for reasons that are more practical and do not take up time and effort. This is the reason why college students are the target for consumers who are often targeted for marketing products to sell well. How to get loyal customers is often done by giving price discounts for their product. The purpose of this study is to conduct an analysis of customer loyalty in the online marketplace who affected by price discounts in their product. This research is quantitative research. The sample used consisted of 60 people who decisions in 2018 and 2019 psychology students in Surabaya State University. This sample is taken by purposive sampling method. Data are collected by using a questionnaire with a Likert scale as a measurement and will be analyzed with a simple linear regression technique that helps by the SPSS program. The results of this study are, there is a significant positive influence on price discounts and consumer loyalty in online marketplace users.
\end{abstract}

Keywords: consumer loyalty; online marketplace; price discount.

\section{PENDAHULUAN}

Mahasiswa adalah generasi yang hidup berdampingan dengan teknologi komunikasi saat ini. Untuk melakukan aktivitas seperti berbelanja, mahasiswa juga telah banyak yang menggunakan online marketplace. Mahasiswa lebih suka menggunakan online marketplace karena lebih membutuhkan sedikit tenaga dan waktu. Hanya tinggal klik tombol-tombol pada gawai dan pesananpun siap untuk diantar hingga ke rumah konsumen. Hal tersebut lah yang menjadikan mahasiswa sebagai target konsumen yang seringkali dituju untuk pemasaran produk agar laris terjual. Berdasarkan survei yang dilakukan oleh lembaga riset Snapchart di tahun 2018 sebanyak 80\% pemuda di usia 15-24 tahun menjadi pembelanja terbanyak pada e-commerce (Tashandra, 2018).

Di Indonesia, terdapat banyak online marketplace dan beberapa diantaranya sudah tidak asing lagi dikalangan masyarakat. Oleh karena itu timbul berbagai macam cara promosi yang dilakukan oleh berbagai macam online marketplace supaya dapat bertahan dalam persaingan yang kian ketat. Cara yang dilakukan para pelaku pasar untuk mengatasi persaingan dan mendapatkan konsumen yang loyal. Menurut Sukesi, loyalitas adalah suatu pengukuran tentang bagaimana kemungkinan besar konsumen akan kembali untuk membangun hubungan dengan organisasi tersebut (Sukesi, 2013). Pelanggan yang loyal akan selalu membeli secara teratur dan berulang-ulang pada tempat yang sama (Mu'ah, 2014).

Cara memperoleh konsumen yang loyal sering kali dilakukan dengan memberikan potongan harga atau diskon. Potongan harga biasa didefinisikan dengan kegiatan untuk mengurangi harga suatu produk, supaya harga produk tersebut bisa di bawah harga normal dan dilakukan pada jangka waktu tertentu. Harga produk akan mengalami pengurungan dari harga normal ketika sedang dalam periode tertentu untuk meningkatkan volume penjualan. Menurut Schindler diskon memiliki empat macam, yakni periodic discount, promotional discount, early-purchase discount, dan late-purchase discount (Schindler, 2012). 
Dewi dan Kusumawati (2018) sebelumnya telah melakukan penelitian mengenai pengaruh diskon terhadap keputusan pembelian dan kepuasan pelanggan bisnis online. Melalui penelitian tersebut didapatkan hasil yakni variabel X (diskon) memiliki pengaruh yang signifikan terhadap keputusan pembelian dan customer satisfaction. Penelitian tersebut belum menjelaskan secara detail apakah pelanggan akan kembali pada online marketplace yang sama saat ingin membeli produk yang diinginkannya setelah diberikan potongan harga.

Penelitian ini bertujuan menganalisis pengaruh pemberian diskon terhadap loyalitas konsumen khususnya pada mahasiswa. Penelitian dilakukan pada mahasiswa mengingat mahasiswa sebagai generasi yang tumbuh dalam kemajuan teknologi dan perkembangan online marketplace.

\section{KAJIAN PUSTAKA DAN PENGEMBANGAN HIPOTESIS}

\section{Potongan Harga}

Potongan harga sering sekali ditemukan dalam proses transaksi jual beli. Kebanyakan bertujuan untuk meningkatkan minat beli dari para konsumen. Hal ini terjadi karena dengan adanya diskon konsumen akan tertarik untuk membelanjakan uangnya pada produk yang menawarkan diskon. Diskon sendiri merupakan pengurangan harga pada suatu produk yang sebelumnya berharga normal yang dilakukan pada saat periode tertentu untuk meningkatkan volume penjualan (Ghristian, 2016). Dari pengertian tersebut dapat diketahui bahwa diskon tidak diberikan secara terus-menerus, melainkan ada suatu waktu tertentu yang bertujuan untuk meningkatkan penjualan. Pemberian diskon salah satunya bertujuan untuk mengikat konsumen (Putra et al., 2018). Diskon dapat mengikat konsumen untuk mau membeli barang yang berdiskon. Hal ini dikarenakan diskon dapat menguntungkan konsumen. Konsumen tidak perlu membayar sesuai harga normal, namun di bawah harga normal. Perilaku tersebut sesuai dengan manusia sebagai makhluk ekonomi, yang mana manusia memilih hasil terbaik dengan usaha sedikit (Tjiptodjojo, 2012).

Doong (dalam Faesol, 2014) menyatakan bahwa diskon yang diberikan oleh sebuah toko dapat membentuk perilaku konsumen, kemudian membentuk kepuasan, dan loyalitas konsumen. Diskon dapat membuat konsumen berfikir atau bahkan langsung tertarik untuk membeli produk yang didiskon. Proses berfikir dan tertarik dengan suatu produk tersebut merupakan proses psikologis konsumen. Proses tersebut meliputi kognisi dan afeksi yang memengaruhi tindakan (Tjiptodjojo, 2012). Proses kognisi bisa berupa konsumen berfikir mengenai kelebihan suatu barang atau jasa, afeksi berupa perasaan konsumen terhadap suatu barang atau jasa. Hasil dari berfikir dan merasakan tersebut yang kemudian menimbulkan suatu perilaku atau keputusan untuk membeli atau tidak membeli suatu barang atau jasa. Dengan adanya potongan harga konsumen akan merasa puas dengan barang yang dia beli dengan harga diskon. Konsumen tidak merasa bersalah, karena mereka hanya membayar produk tersebut dengan harga di bawah harga normal. Hal ini juga akan mendorong konsumen untuk membelanjakan uangnya lagi di toko yang memberikan diskon.

Schindler (2012) menyatakan bahwa terdapat beberapa jenis diskon, yakni sebagai berikut. (1) Periodic Discounts, diskon ini diberikan pada periode-periode tertentu. Ketika tidak dalam periode diskon produk yang ditawarkan akan memiliki harga normal. Namun ketika dalam periode diskon biasanya akan ada barang yang bertuliskan "sale". (2) Promotional Discounts, diskon jenis ini digunakan untuk mengomunikasikan suatu produk kepada konsumen. Dengan memasang diskon pada produk tersebut, maka akan menarik konsumen untuk mencari tahu mengenai produk yang didiskonkan. (3) EarlyPurchase Discounts, diskon jenis ini banyak digunakan dalam industri yang menawarkan produk berupa jasa. (4) Late-Purchase Discounts, diskon jenis ini biasanya terdapat pada barang yang sudah lama berada di toko. Tujuannya tidak lain adalah untuk menjual produk tersebut supaya laku terjual. Contohnya seperti diskon cuci gudang ataupun diskon akhir tahun.

\section{Loyalitas Konsumen}

Menurut Hudson (dalam Sukesi, 2013) loyalitas konsumen adalah suatu pengukuran mengenai kemungkinan besar konsumen akan kembali menjalin hubungan dengan organisasi tersebut. Loyalitas 
Salsabila Wulandari Aryatiningrum \& Athiyyah Isna Insyirah. Pengaruh Price Discount terhadap Loyalitas Konsumen pada Pengguna Online Marketplace

konsumen pada suatu produk tidak hanya diukur melalui pembelian kembali produk atau jasa yang telah mereka beli sebelumnya, tetapi konsumen juga akan timbul komitmen dan perasaan positif terhadap toko tersebut. Contohnya dengan merekomendasikan pada orang-orang terdekat agar membeli produk atau menggunakan jasa pada organisasi tersebut (Verhoef, et al, 2002 dalam Mu'ah, 2014). Loyalitas konsumen terbagi menjadi dua kelompok, yaitu brand loyality dan store loyality. Loyalitas pada suatu brand diartikan sebagai pembelian secara berulang pada brand atau store yang sama secara berkala dan terus menerus, sedangkan loyalitas pada toko diartikan sebagai perilaku konsumen yang secara konsisten membeli brand yang ia ingikan pada toko tertentu (Dwiastuti, Rini; Shinta, Agustina; Isaskar, 2012). Pelanggan yang memiliki keloyalitasan secara tidak langsung akan melakukan pembelian secara terus menerus dan berulangkali pada tempat yang sama agar keinginannya terpuaskan (Suryanti, 2015).

Griffin (dalam Suryanti, 2015) berpendapat bahwa pelanggan yang memiliki keloyalitasan pada suatu barang atau toko dapat dilihat melalui karakteristik pelanggan tersebut, yaitu sebagai berikut. (1) Konsumen melakukan pembelian produk atau jasa yang ditawarkan oleh perusahaan. (2) Konsumen melakukan pembelian berulang secara berkala. (3) Menawarkan atau merekomendasikan produk atau jasa tersebut kepada orang lain. (4) Tidak ada ketertarikan pada produk atau jasa yang ditawaran oleh pesaing.

Sementara itu Marconi (dalam Priyanto 1998, dalam Mu'ah, 2014) menuliskan bahwa terdapat faktor yang dapat memengaruhi loyalitas pada konsumen terhadap suatu produk maupun jasa yaitu sebagai berikut. (1) Nilai (harga dan kualitas), konsumen yang menggunakan suatu produk ataupun jasa dengan jangka waktu yang lama dapat membuat konsumen memiliki loyalitas. Kualitas, standar dan harga perlu diperhatikan agar konsumen tidak merasa kecewa telah membeli kembali produk atau jasa dari toko atau brand tersebut. (2) Citra (Reputasi dari perusahaan atau brand tersebut) Apabila perusahaan atau brand memiliki citra yang bagus, maka konsumen akan menunjukkan loyalitas pada brand dan toko tersebut. (3) Rasa nyaman dan mudahan dalam memperoleh produk. Walaupun terdapat banyak tekanan dan permintaan pasar pada produk, hendaknya perusahaan tetap memberikan kenyaman dan kemudahan untuk pelanggan ketika membeli produk tersebut. (4) Rasa puas, apabila konsumen merasakan kepuasan ketika membeli produkatau menggunakan suatu jasa pada perusahaan tersebut, maka loyalitas pada konsumen akan timbul. (4) Pelayanan, perusahaan yang memiliki pelayanan yang berkualitas akan berdampak pada loyalitas suatu konsumen pada brand tersebut. (4) Pemberian garansi dan jaminan ketika pelanggan membeli suatu produk atau menggunakan jasa pada perusahaan tersebut.

Selain itu loyalitas pada pelanggan juga dapat ditinjau oleh beberapa aspek salah satunya aspek yang dikemukakan oleh Griffin (dalam Mu'ah, 2014) yaitu sebagai berikut. (1) Repeat Purchase, melakukan pembelian pada suatu produk secara teratur. (2) Referrals, mengajak kolega dari konsumen untuk membelanjakan uangnya pada produk di suatu toko. (3) Retention, tidak mudah tertarik pada produk dari pesaing perusahaan tersebut.

\section{Hubungan antar Variabel}

Untuk menemukan hubungan antara variabel $\mathrm{X}$ (price discount) dengan variabel $\mathrm{Y}$ (loyalitas konsumen) maka perlu adanya studi mengenai penelitian-penelitian terdahulu. Pada penelitian yang dilakukan oleh Dewi dan Kusumawati pada tahun 2018 mengenai pengaruh diskon terhadap keputusan pembelian dan kepuasan pelanggan. Penelitian ini memiliki populasi berupa pelanggan Traveloka dan sampel sebanyak 115 responden. Hasil dari penelitian ini menyatakan bahwa pemberian diskon memiliki pengaruh yang signifikan terhadap keputusan pembelian dan kepuasan pelanggan (Dewi \& Kusumawati, 2018). Namun masih belum menjelaskan tentang pengaruh diskon terhadap loyalitas pelanggan.

Adapun penelitian mengenai pengaruh ekuitas merek, potongan harga, dan kepuasan pelanggan terhadap loyalitas pelanggan yang dilakukan Arsuni. Sampel pada penelitian ini adalah konsumen yang pernah membeli produk Daihatsu dan tinggal di Muara Teweh. Hasil dari penelitian ini menunjukkan bahwa ekuitas merek, potongan harga, dan kepuasan pelanggan memiliki pengaruh yang signifikan terhadap loyalitas konsumen (Arsuni, 2020). 
Dari kedua penelitian yang telah dilakukan terlebih dahulu menjadikan sumber bagi penelitian ini dalam menentukan hubungan antar variabel. Pada penelitian Arsuni variabel potongan harga memiliki pengaruh yang signifikan terhadap variabel loyalitas konsumen, sehingga dapat diambil hopitesis berupa:

H0 : Pemberian potongan harga tidak berpengaruh positif terhadap loyalitas konsumen pada pengguna online marketplace.

H1 : Pemberian potongan harga berpengaruh positif terhadap loyalitas konsumen pada pengguna online marketplace.

\section{METODE PENELITIAN}

Penelitian yang dilakukan menggunakan jenis pendekatan kuantitatif. Untuk pengambilan sampel peneliti menggunakan teknik nonprobability sampling dan untuk pengambilan sampel dilakukan dengan menggunakan teknik purposive sampling. Hal ini dilakukan peneliti untuk menentukan kriteria sampel yang akan digunakan dalam suatu penelitian (Sugiyono, 2012). Purposive sampling dipilih dikarenakan sampel yang akan diambil oleh peneliti haruslah dapat mewakili karakteristik yang dibutuhkan di penelitian ini (Jannah, 2018). Karakteristik sampel yang dipertimbangan dalam penelitian ini yaitu mahasiswa psikologi Universitas Negeri Surabaya angkatan 2018-2019 yang pernah melakukan pembelian produk secara online disebuah marketplace.

Skala likert digunakan peneliti untuk memperoleh data. Skala ini biasa digunakan dalam penelitian karena penggunaannya yang relatif mudah (Budiaji, 2013). Pertanyaan yang diberikan berupa pertanyaan favorable dan unfavorable. Responden diminta untuk menyatakan kesetujuan atau ketidaksetujuan yang terdiri dari 4 alternatif jawaban yaitu Sangat Setuju yang ditandai dengan SS dengan skor 4, Setuju yang ditandai dengan S dengan skor 3, Tidak Setuju yang ditandai dengan TS dengan skor 2, dan Sangat Tidak Setuju yang ditandai dengan STS dengan skor 1 (Agung, 2012). Untuk pertanyaan unfavorable akan dilakukan penilaian sebaliknya yaitu Sangat Setuju dengan skor 1, Setuju dengan skor 2, begitu pula seterusnya. Data akan dikumpulkan menggunakan metode survey dengan instrumen berupa angket atau kuisoner yang telah dibuat dan disebarkan secara online melalui Google Form. Survey sendiri merupakan kegiatan untuk menghimpun informasi terkait suatu populasi dengan menanyakan pertanyaan pada sampelnya (Nugroho, 2018). Tiap item dalam instrument survey diuji validitasnya menggunakan aplikasi SPSS 23 , hal ini supaya data yang dihasilkan bisa valid karena item yang digunakan untuk menghimpun data valid. Data yang hendak dianalisis haruslah berdistribusi normal, sehingga digunakan Uji One-Sample Kolmogorov-Smirnov. Ketika data telah berdistribusi normal barulah data bisa dianalisis lebih lanjut. Dalam penelitian ini untuk menemukan ada atau tidaknya pengaruh variabel $\mathrm{X}$ terhadap variabel $\mathrm{Y}$ digunakan uji koefisien determinasi $\left(\mathrm{R}^{2}\right)$, uji regresi linear sederhana, dan uji F (ANOVA) yang dilakukan dengan menggunakan software SPSS 23.

\section{HASIL DAN PEMBAHASAN}

\section{Deskrpisi Responden}

Responden penelitian ini berjumlah 60 orang yang berasal dari angkatan 2018 dan 2019 mahasiswa psikologi Universitas Negeri Surabaya. Mahasiswa angkatan 2019 berjumlah 12 mahasiswa dan memiliki persentase $20 \%$ dari total responden dan 48 mahasiswa angkatan 2018 yang mana memiliki persentase sebesar $80 \%$ dari keseluruhan responden. Berdasarkan data yang terhimpun diketahui pengguna platform Shopee sebanyak 53 mahasiswa, Tokopedia sebanyak 3 mahasiswa, dan 4 sisanya menggunakan platform online marketplace lainnya.

\section{Uji Validitas Item}

Dari tabel 1, dapat dilihat bahwa seluruh item yang digunakan didalam kuesioner untuk mengukur Variabel X maupun $\mathrm{Y}$ adalah Valid. Hal ini karena semua $\mathrm{T}$ Hitung lebih besar daripada $\mathrm{T}$ Tabel $5 \%$ untuk $\mathrm{N}=60$. 
Salsabila Wulandari Aryatiningrum \& Athiyyah Isna Insyirah. Pengaruh Price Discount terhadap Loyalitas Konsumen pada Pengguna Online Marketplace

\section{Uji Normalitas}

Nilai signifikansi uji normalitas Kolmogorov-Smirnov sebesar 0,200. Syarat suatu data berdistribusi normal menurut uji normalitas Kolmogorov-Smirnov adalah nilai signifikansi lebih dari 0,05. Sehingga dari tabel tersbeut dapat diperoleh kesimpulan bahwa data pada penelitian ini berdistribusi normal karena 0,200>0,05. Sehingga dapat dilanjutkan untuk menentukan adanya pengaruh variabel $X$ terhadap Y dengan menggunakan Uji Regresi Linear Sederhana.

Tabel 1.

HASIL UJI VALIDITAS

\begin{tabular}{cccccc}
\hline Variabel & No. Item & T Hitung & T Tabel $\mathbf{5 \%}(\mathbf{6 0})$ & Sig & Kriteria \\
\hline Potongan Harga & 1 & 0,629 & 0,254 & 0,000 & Valid \\
& 2 & 0,726 & 0,254 & 0,000 & Valid \\
& 3 & 0,626 & 0,254 & 0,000 & Valid \\
& 4 & 0,618 & 0,254 & 0,000 & Valid \\
& 5 & 0,432 & 0,254 & 0,001 & Valid \\
& 6 & 0,534 & 0,254 & 0,000 & Valid \\
& 7 & 0,464 & 0,254 & 0,000 & Valid \\
& 8 & 0,661 & 0,254 & 0,000 & Valid \\
& 9 & 0,482 & 0,254 & 0,000 & Valid \\
& 10 & 0,749 & 0,254 & 0,000 & Valid \\
& 1 & 0,717 & 0,254 & 0,000 & Valid \\
& 2 & 0,674 & 0,254 & 0,000 & Valid \\
& 3 & 0,748 & 0,254 & 0,000 & Valid \\
& 4 & 0,656 & 0,254 & 0,000 & Valid \\
& 5 & 0,613 & 0,254 & 0,000 & Valid \\
& 6 & 0,742 & 0,254 & 0,000 & Valid \\
& 7 & 0,765 & 0,254 & 0,000 & Valid \\
& 8 & 0,638 & 0,254 & 0,000 & Valid \\
& 9 & 0,691 & 0,254 & 0,000 & Valid \\
& 10 & 0,679 & 0,254 & 0,000 & Valid \\
\hline
\end{tabular}

\section{Koefisien Determinasi $\left(\mathbf{R}^{2}\right)$}

Hasil penelitian menunjukkan $\mathrm{R}$ memiliki korelasi hubungan sebesar 0,678 dan diperoleh koefisien determinan (R Square) sebesar 0,459. Dalam hal ini dapat diartikan bahwa koefisien determinan ( $R$ Square) memiliki pengaruh sebesar 45,9\% pada variabel $\mathrm{Y}$ atau dengan kata lain variabel price discount terhadap variabel loyalitas konsumen memiliki pengaruh sebesar $45,9 \%$ sementara sisanya dapat dipengaruhi oleh variabel lain yang tidak dibahas dalam penelitian ini.

\section{Uji Regresi Linear Sederhana}

Tabel 2 menjelaskan bahwa nilai $\mathrm{F}$ Hitung $=49,269$ dan tingkat signifikansinya adalah 0,000 yang mana tingkat signifikansi ini kurang dari 0,05. Sehingga, ada pengaruh variabel x (price discount) terhadap variabel y (loyalitas konsumen).

Tabel 2.

HASIL UJI F

\begin{tabular}{llrrrrr}
\hline Model & & Sum of Squares & df & Mean Square & F & Sig. \\
\hline 1 & Regression & 598,443 & 1 & 598,443 & 49,269 &, $000^{\mathrm{b}}$ \\
& Residual & 704,490 & 58 & 12,146 & & \\
& Total & 1302,933 & 59 & & & \\
\hline
\end{tabular}

Dari tabel 3, dapat dilihat bahwa nilai konstan (a) sebesar 9,037 dan nilai variabel Price Discount (b atau koefisien regresi) sebesar 0,746. Angka-angka tersebut dapat dituliskan dalam persamaan (1).

$Y=9,037+0,746 X$ 
Persamaan yang terbentuk dapat diterjemahkan bahwasannya konstanta yang diperoleh sebesar 9,037 mengindikasikan nilai koefisien variabel Price Discount sebesar 9,037. Kemudian koefisien regresi sebesar 0,746 menunjukkan bahwa tiap adanya penambahan $1 \%$ nilai Price Discount, maka nilai Loyalitas Konsumen akan bertambah sebanyak 0,746. Koefisien regresi didapat nilai positif, sehingga variabel $\mathrm{X}$ berpengaruh positif terhadap variabel $\mathrm{Y}$.

Tabel 3.

\section{KOEFISIEN REGRESI}

\begin{tabular}{llrrrrr}
\hline & & \multicolumn{7}{c}{$\begin{array}{c}\text { Standardized } \\
\text { Unstandardized Coefficients } \\
\text { Coefficients } \\
\text { Medel }\end{array}$} & & B & Std. Error & Beta & \multicolumn{1}{c}{ t } & \multicolumn{1}{c}{ Sig. } \\
\hline 1 & (Constant) & 9,037 & 3,227 & & 2,801 &, 007 \\
& Price Discount &, 746 &, 106 &, 678 & 7,019 &, 000 \\
\hline
\end{tabular}

\section{Pengaruh Diskon terhadap Loyalitas}

Dari hasil tersebut dapat dilihat bahwa potongan harga bisa membuat konsumen menjadi loyal terhadap suatu produk, jasa, atau online marketplace. Dengan memberikan potongan harga kepada konsumen, konsumen akan mempertimbangkan untuk kembali bertransaksi dengan menggunakan online marketplace yang telah memberikannya potongan harga. Potongan harga juga dapat mengikat konsumen karena konsumen merasa puas, hal ini tentu akan membangun loyalitasnya terhadap suatu online marketplace.

Adapun hasil dari penelitian ini sesuai dengan penelitian terdahulu yang dilakukan oleh Arsuni. Dalam penelitian yang dilakukan Arsuni terhadap konsumen produk Daihatsu dan bertempat di Muara Teweh menghasilkan kesimpulan bahwa potongan harga memiliki pengaruh yang signifikan terhadap loyalitas konsumen. Sama halnya dengan hasil dari penelitian ini.

Implikasi manajerial dari hasil penelitian ini berguna bagi perusahaan penyedia online marketplace dalam mengelola konsumennya terutama dari kalangan mahasiswa, di antaranya adalah sebagai berikut. Adanya penawaran diskon membuat konsumen suatu online marketplace menjadi loyal. Hal ini sesuai dengan hasil penelitian yakni potongan harga berpengaruh terhadap loyalitas konsumen. Mahasiswa merupakan salah satu target pasar yang ideal untuk perusahaan online marketplace hal ini dikarenakan mahasiswa yang sudah terbiasa teknologi komunikasi pada kehidupan sehari-hariya begitupun penggunaan teknologi komunikasi untuk berbelanja. Pelanggan yang loyal pada suatu online marketplace salah satu perilaku yang timbul adalah merekomendasikan online marketplace tersebut kepada orang lain. Khususnya bagi mahasiswa yang akrab dengan teknologi komunikasi salah satunya adalah media sosial akan mudah untuk menyebarkan pengalaman berbelanja di suatu online marketplace pada orang lain.

\section{KESIMPULAN}

Dari penelitian yang telah dilakukan dapat disimpulkan bahwa price discount berpengaruh positif terhadap loyalitas pelanggan pada mahasiswa psikologi Universitas Negeri Surabaya yang pernah menggunakan online marketplace sebagai media untuk berbelanja. Dalam penelitian ini loyalitas yang terbentuk pada mahasiswa dipengaruhi oleh pemberian price discount pada produk yang ditawarkan oleh platform online marketplace. Semakin sering marketplace tersebut memberikan potongan harga maka semakin sering pula mahasiswa kembali untuk berbelanja dan loyalitas akan terbentuk. Karena hal itu juga mahasiswa tidak segan untuk merekomendasikan dan mengajak orang terdekatnya agar berbelanja pada platform online marketplace yang sama dengannya. Sebagian dari mahasiswa pada penelitian ini juga menyatakan kesetiannya pada platform online marketplace yang mereka gunakan karena adanya potongan harga yang ditawarkannya. Mereka tidak tertarik dengan tawaran yang diajukan platform online shopping lainnya. Penjelasan ini sejalan dengan Grifin (dalam Suryanti, 2015) mengenai karakteristik pelanggan yang memiliki loyalitas yaitu melakukan pembelian produk atau jasa yang ditawarkan oleh perusahaan, Konsumen melakukan pembelian berulang secara berkala, 
Salsabila Wulandari Aryatiningrum \& Athiyyah Isna Insyirah. Pengaruh Price Discount terhadap Loyalitas Konsumen pada Pengguna Online Marketplace

Menawarkan atau merekomendasikan produk atau jasa tersebut kepada orang lain, Tidak ada ketertarikan pada produk atau jasa yang ditawaran oleh pesaing.

Selama penelitian ini dilakukan, peneliti menyadari atas keterbatasan yang ada. Sampel pada penelitian ini masih terbilang kurang dan alangkah baiknya jika populasi yang diambil tidak hanya dilingkup Universitas saja. Jumlah sampel juga diharapkan lebih banyak lagi agar dapat meningkatkan reliabilitas. Selain itu untuk variabel yang digunakan dalam penelitian loyalitas pelanggan, peneliti menyarakan agar juga lebih diperluas tidak hanya berpaku pada satu variabel konstan, misalnya variabel citra toko, kualitas pelayanan, atau kualitas produk yang juga dapat mempengaruhi loyalitas pelanggan.

\section{DAFTAR PUSTAKA}

Agung, A. A. (2012). Metodologi Penelitian Bisnis. Malang: Universitas Brawijaya Press.

Arsuni. (2020). PENGARUH EKUITAS MEREK, DISKON HARGA DAN KEPUASAN PELANGGAN TERHADAP LOYALITAS PELANGGAN PT. ASTRA INTERNATIONAL DAIHATSU DI KOTA MUARA TEWEH. Jurnal Ekonomi Dan Bisnis, 4(1), 1-17. https://doi.org/10.1017/CBO9781107415324.004

Budiaji, W. (2013). Skala pengukuran dan jumlah respon skala likert (the measurement scale and the number of responses in likert scale). Ilmu Pertanian Dan Perikanan, 2(2), 127-133.

Dewi, K. I., \& Kusumawati, A. (2018). Pengaruh Diskon Terhadap Keputusan Pembelian Dan Kepuasan Pelanggan Bisnis Online. Jurnal Administrasi Bisnis (JAB)|, 56(1), 155-163. www.internetworldstats.com

Dwiastuti, Rini; Shinta, Agustina; Isaskar, R. (2012). Ilmu Perilaku Konsumen. Malang: Universitas Brawijaya Press. http://www.mendeley.com/import/

Faesol, A. (2014). Efektivitas Diskon dan Hadiah sebagai Sarana Promosi Penjualan untuk Menarik Niat Beli Konsumen pada Bumbu Magic Lezat. Manajemen Bisnis, 3(1).

Ghristian, I. D. (2016). Citra Merek, Dan Iklan Terhadap Minat Beli Celana Jeans Levi's Di Surabaya. Journal of Business and Banking, 5(2), 319-336. https://doi.org/10.14414/jbb.v5i2.552

Mu'ah. (2014). LOYALITAS PELANGGAN Tinjauan Aspek Kualitas Pelayanan dan Biaya Peralihan. Sidoarjo: Zifatama Publisher.

Nugroho, E. (2018). Prinsip-Prinsip Menyusun Kuesioner. Malang: Universitas Brawijaya Press.

Putra, N. I., Pangestuti, E., \& Devita, L. D. R. (2018). Pengaruh Diskon dan Pemberian Hadiah Terhadap Pembelian Impulsif Pada Fashion Retail Matahari Department Store di Malang. Jurnal Administrasi Bisnis (JAB), 61(4), 1-9.

Schindler, R. M. (2012). Pricing strategies. California: SAGE Publications, Inc.

Sugiyono. (2012). Metode Penelitian Kuantitatif. Sidoarjo: Zifatama Publishing.

Sukesi. (2013). Loyalitas pelanggan produk terasi rebon. Surabaya: Smartekindo.

Tashandra, N. (2018). 80 Persen Konsumen Belanja Online Orang Muda dan Wanita. Kompas.Com. https://lifestyle.kompas.com/read/2018/03/22/155001820/80-persen-konsumen-belanja-onlineorang-muda-dan-wanita?page=all

Tjiptodjojo, K. (2012). Odd Price: Harga, Psikologi Dan Perilaku Konsumen Dalam Purchase Decision 
Making. Jurnal Manajemen Maranatha, 11(2), 112845. 